DEPARTMENT OF ECONOMICS

\title{
Annotated Potron Bibliography
}

\section{Wilfried Parys}

\author{
UNIVERSITY OF ANTWERP \\ Faculty of Applied Economics \\ Stadscampus \\ Prinsstraat 13, B.213 \\ BE-2000 Antwerpen \\ Tel. +32 (0)3 2654032 \\ Fax +32 (0)3 2654799 \\ http://www.ua.ac.be/tew
}




\title{
FACULTY OF APPLIED ECONOMICS
}

\author{
DEPARTMENT OF ECONOMICS \\ Annotated Potron Bibliography \\ Wilfried Parys
}

RESEARCH PAPER 2010-003

FEBRUARY 2010
University of Antwerp, City Campus, Prinsstraat 13, B-2000 Antwerp, Belgium Research Administration - room B.213 phone: (32) 32654032 fax: (32) 32654799
e-mail: joeri.nys@ua.ac.be

The papers can be also found at our website: www.ua.ac.be/tew (research $>$ working papers) \& www.repec.org/ (Research papers in economics - REPEC)

$D / 2010 / 1169 / 003$ 


\title{
ANNOTATED POTRON BIBLIOGRAPHY
}

\section{Wilfried PARYS}

February 2010

\begin{abstract}
Given the rising status of Maurice Potron (1872-1942) as an important pioneer in the history of economic analysis, given that he never published in mainstream economic journals, and given that many of his writings are hard to find, it is interesting to construct a list of Potron's published and unpublished writings. The first such list was produced in 2004 by Abraham-Frois and Lendjel, and consisted of 24 entries. Since 2004 a large number of unknown publications and unpublished manuscripts were found, and now a much more comprehensive Potron bibliography can be constructed.
\end{abstract}

\section{JEL Classification Code: B3}

Keywords: Potron, bibliography, mathematical economics, linear economic models, input-output analysis.

Acknowledgements. This Potron Bibliography results from a five year research in very informative collaboration with Christian Bidard and Guido Erreygers, on the life and work of Maurice Potron, which has led to a joint publication (see footnote 1). During these years, many forgotten writings by Potron were rediscovered. In the context of our Potron research, useful help was provided by Robert Bonfils, Christian de Borchgrave, Chantal Dufour, Jocelyne Dufour, Gilbert Abraham-Frois and Emeric Lendjel, Thomas Hawkins, Kris Van de Casteele, the staff of the National Archives in Paris, the Institut Catholique de Paris, the Archives Jésuites de la Province de France in Vanves, the Université Catholique de Lille, the Université Catholique de l'Ouest in Angers, and the Municipal Archives in Vannes. Special thanks to Anne-Catherine Putz (Mouvement Chrétien des Cadres et Dirigeants, Paris), who surprised me in June 2006 by providing me with a copy of Potron's "unfindable" first economic article (the 1911 Echos paper). My greatest debt is to Christian Bidard for reading my innumerable drafts and suggesting many additional references. All corrections and additions are welcome.

Address for correspondence. Wilfried Parys, Department of Economics, University of Antwerp, Prinsstraat 13, 2000 Antwerp, Belgium; wilfried.parys@ua.ac.be 


\section{Introduction}

Most textbooks on mathematics for economists heavily concentrate on two topics: differential calculus and linear algebra. The treatment of the first topic can be enriched by historical remarks on Augustin Cournot's pioneering use of differential calculus in economics in 1838, and by the well known stories about the neglect of Cournot's highly original work by his contemporaries. Recently it became obvious that another remarkable story of neglect exists, this time with respect to pioneering use of linear algebra in economics. Again it involves a French mathematician, namely the Jesuit Maurice Potron (1872-1942), engineer of the Ecole Polytechnique (admitted in 1890, graduated in 1892) and $\mathrm{PhD}$ in mathematics from Paris (1904). Potron presented his innovative economic model in two different periods of his career: 1911-1914 and 1935-1942. Inspired by the encyclical Rerum Novarum and by his knowledge of nonnegative matrices, Potron applied sophisticated and relevant linear algebra to economics as early as 1911, many decades before the well known protagonists of linear models of production, like Wassily Leontief, Paul Samuelson, Robert Solow, Tjalling Koopmans, Richard Stone, Gérard Debreu, Herbert Simon, Kenneth Arrow (note that I named eight Nobel laureates here), John von Neumann, Piero Sraffa, Michio Morishima, David Gale, Harold Kuhn, and many others.

Potron's economics was hardly noticed during his lifetime, up until more than half a century after his death, for various reasons. He used unrealistic assumptions and nonstandard notations. He rarely cited other economists, and published in Catholic and mathematical journals, far away from the mainstream of economics. Actually, he ignored the orthodox economics of his contemporaries, and despite (or sometimes because of) his lack of realism, Potron invented new analytical tools that became part of mainstream economic analysis only many decades later. Already in the period 1911-1914, he constructed a sort of comprehensive input output model and pioneered the economic application of the most famous theorem in the theory of nonnegative matrices (Perron-Frobenius theorem). Moreover, he anticipated the Hawkins-Simon condition, and he established some duality properties between the solutions of his quantity system and his price system. ${ }^{1}$

\footnotetext{
${ }^{1}$ The present text concentrates on bibliographical aspects. For more details on Potron's career and the exact nature of his original economic model, I refer to Bidard, C., Erreygers, G. and Parys, W. (2009). 'Our Daily Bread': Maurice Potron, from Catholicism to Mathematical Economics. European Journal of the History of Economic Thought, 16: 123-154.
} 
In his famous survey on the transformation problem, Samuelson (1971: 400) coined the phrase "this Age of Leontief and Sraffa", to indicate that from the 1960s on every modern economist knew how to handle linear models of production. ${ }^{2}$ At the same time historians of economics searched for unknown early pioneers, and rehabilitated the forgotten works of Dmitriev, Charasoff, Remak, and others, but all economists overlooked Potron.

In 1969 the Jesuit Paul Droulers, a historian of social Catholicism, published his book Politique Sociale et Christianisme. Le Père Desbuquois et l'Action Populaire. Débuts. Syndicalisme et Intégristes (1903-1918), Paris: Editions Ouvrières. In this book (see especially pp. 214-216), Droulers very explicitly praised Potron's pioneering mathematical economics, but other historians of church history didn't understand Potron's relevance, and historians of economics didn't notice Droulers or Potron. Only many years later Emeric Lendjel (2000), after doing research on the economists of the Ecole Polytechnique in the 1930s, drew the attention of the economists to Potron as the most remarkable precursor of Leontief and Sraffa. ${ }^{3}$ The status of Potron was raised even more by additional writings from Abraham-Frois and Lendjel, especially by the publication of their 2004 book that contains a selection of economic writings by Potron, and by including an entry on Potron in the new edition of the International Encyclopedia of the Social Sciences. ${ }^{4}$ Moreover, in the near future an English translation of all of Potron's economic texts will be available (Bidard and Erreygers 2010, forthcoming). These French and English editions (plus many recent articles on Potron) should give Potron his long overdue place in the history of economics.

Given that many of his writings are hard to find, it is useful to produce a list of Potron's published and unpublished writings. The first version of a Potron bibliography was presented by Abraham-Frois \& Lendjel (2004: 209-210) and consisted of 24 items. During the past five years, many overlooked economic publications and unpublished manuscripts have come to light, and thereby a list of about eighty Potron items can be constructed.

\footnotetext{
2 See: Samuelson, P. A. (1971), "Understanding the Marxian Notion of Exploitation: A Summary of the SoCalled Transformation Problem between Marxian Values and Competitive Prices", Journal of Economic Literature, 9: 399-431. Some other references that I use in the present paragraph (Lendjel 2000, Abraham-Frois and Lendjel 2004, Bidard and Erreygers 2010) contain republications of Potron's work, and thus the complete reference can be found in the Potron bibliography below (see Section 2: Republications after 1942).

${ }^{3}$ Lendjel's discovery of Potron caught the special attention of Abraham-Frois end 1999. Their first joint paper was: Abraham-Frois, G. \& Lendjel, E. (2001), "Une première application du théorème de Perron-Frobenius à l'économie: l'abbé Potron comme précurseur", Revue d'Economie Politique, 111: 639-665.

${ }^{4}$ Abraham-Frois, G. \& Lendjel, E. (2008), "Potron, Maurice 1872-1942”, in: Darity, W.A. Jr. (Ed.). International Encyclopedia of the Social Sciences. Second Edition. Detroit: Gale. Volume 6, pp. 403-404.
} 
The bibliography below is divided into three sections, and tries to cover all known writings authored or co-authored by Potron. Section 1 lists writings until 1942, the year of Potron's death. It is obvious that many journal articles were also available as offprints, but I mention the offprints only in special cases. Section 2 contains republications after 1942, all very recent, because Potron's work was almost completely neglected in the first decades after his death. In the 1930s Potron produced many articles and booklets that contained exercises and solutions of the examination sessions for the Certificat de Calcul Différentiel et Intégral (C.D.I.) in all the Faculties of France. I list these exercises in Section 3, separated from the rest of the bibliography, because they are so numerous that they would spoil the reader's panorama of Potron's stream of normal publications in Sections 1 and 2.

Although he was not an innovating pioneer in mathematics, Potron was a competent mathematician, who published in prestigious French mathematical journals, and so he was regularly cited in specialist mathematical articles, and even once (on p. 360) by Florian Cajori in his comprehensive classic A History of Mathematics, Second Edition, London: Macmillan, 1919. Many of Potron's mathematical publications were abstracted in the three main review journals of mathematics. I use the traditional abbreviations:

$$
\begin{aligned}
\mathrm{JFM} & =\text { Jahrbuch über die Fortschritte der Mathematik } \\
\mathrm{Zbl} & =\text { Zentralblatt für Mathematik und ihre Grenzgebiete } \\
\mathrm{MR} & =\text { Mathematical Reviews }
\end{aligned}
$$

For JFM, Zbl and MR, I usually provide only the name of the reviewers, because further details are easily found in the electronic databases Zentralblatt MATH (which covers JFM and $\mathrm{Zbl}$ ) and MathSciNet (which covers MR). I include book reviews and citations from other mathematical sources only when some comments seem useful. Potron's main claim to scholarly fame lies not in pure mathematics, but in mathematical economics. Throughout his whole career, references to Potron's economics were rare, inconspicuous and not informative. Because of Potron's importance for economics, I try to mention all these inconspicuous sources that cited Potron's economics during his lifetime and immediately after. ${ }^{5}$

\footnotetext{
${ }^{5}$ For obvious reasons, my bibliographical annotations concentrate on historical references. The most recent reference from economics that I include is Woodbury 1954 (see Potron entry [1939a] below). As mentioned above, Droulers 1969 book is a special case that referred to many of Potron's economic publications, and to his work in general. After 1954, apart from the 1969 book by Droulers (an outlier which was not noticed by economists), no other studies referred to Potron's economics until Lendjel and the $21^{\text {st }}$ century. For the fast growing number of $21^{\text {st }}$ century citations to Potron's economics, see EconLit and other well-known databases.
} 


\section{Section 1. Writings until 1942}

[1901-1902] "Sur la génération de quelques courbes remarquables par le campylographe du P. Marc Dechevrens, S.J.", Annales de la Société Scientifique de Bruxelles, 26 (Seconde Partie - Mémoires): 41-56.

Potron's mathematical study of the campylograph, a sophisticated apparatus to draw geometrical curves, stereoscopic figures and artistic drawings. The first two pages contain an introduction written by the inventor of the campylograph, the Jesuit meteorologist and physicist Marc Dechevrens (1845-1923). Volume 26 of the Annales covers part of 1901 and 1902. Potron's paper in the 'Seconde Partie' was published in 1902. According to information in the 'Première Partie' (p. 76), this work of Father Potron was presented by Father Thirion, in the name of Father Dechevrens, in the Second Section of the meeting held by the "Société Scientifique de Bruxelles" on 21 November 1901 in Ghent.

An offprint of the article was published by Polleunis \& Ceuterick in Brussels in 1902. The Bulletin of the American Mathematical Society, vol. 9, October 1902, p. 70 (list of new publications) mentions: "Potron. Le campylographe du P. Marc Dechevrens. Etude de quelques courbes remarquables tracées avec cet instrument. Paris: Gauthier-Villars, 1902.”

[1904a] Les Groupes d'Ordre $p^{6}$. Paris: Gauthier-Villars, 177 p.

Doctoral dissertation in mathematics. (Faculté des Sciences de Paris, 28 June 1904). The jury consisted of Emile Picard (supervisor), Paul Appell (president) and Henri Poincaré. The reports on the thesis (by Picard) and the oral defense (by Appell) are in the file $\mathrm{AJ}^{16} 5538$, Archives Nationales, Paris. At that time most doctoral dissertations in the Faculté des Sciences obtained the grade of "très honorable", but Potron received only "honorable". (See the lists in Revue Internationale de l'Enseignement, 1905, vol. 50, pp. 141-143, 148, 154).

Potron's dissertation is the first attempt to list the groups whose number of elements is the sixth power of a prime number. It is occasionally cited in the mathematical literature of the $20^{\text {th }}$ and $21^{\text {st }}$ century. Two early examples of citations are: McKelden, A. M. (1906), "Groups of order $2^{\mathrm{m}}$ that contain cyclic subgroups of order $2^{\mathrm{m}-3}$, , American Mathematical Monthly, 13, nos. 6-7, (June-July): 121-136; and Miller, G.A. (1907). “Third report on recent progress in the theory of groups of finite order", Bulletin of the American Mathematical Society, 14, no. 2: 78-91. Two $21^{\text {st }}$ century papers that cite Potron's dissertation are: Besche, H.U., Eick, B. \& O’Brien, E.A. (2002), “A millennium project: constructing small groups”, International Journal of Algebra and Computation, 12, no. 5: 623-644; and Newman, M.F., O’Brien, E.A. \& Vaughan-Lee, M.R. (2004). "Groups and nilpotent Lie rings whose order is the sixth power of a prime", Journal of Algebra, 278: 383-401. 
[1904b] "Sur quelques groupes d'ordre $p^{6 \%, ~ B u l l e t i n ~ d e ~ l a ~ S o c i e ́ t e ́ ~ M a t h e ́ m a t i q u e ~ d e ~ F r a n c e, ~}$ 32: $296-300$.

Reviewed in JFM by Alfred Loewy.

Potron's note corrects some results of his 1904 dissertation, as is announced by the opening statement: "Cette Note a pour but de rectifier et de compléter les résultats obtenus dans ma Thèse de Doctorat..." This might explain the title used by Potron for the offprint: "Note pour rectifier et compléter les résultats touchant les groupes d'ordre $p^{6}$, Gauthier-Villars, Paris, 1905. I take the reference for this unseen offprint from the Moniteur Bibliographique (see its 1905 list, p. 98, which adds: "Extrait du Bulletin de la Société Mathématique de France"). The Moniteur Bibliographique contains bibliographical lists of works written by Jesuits, up to 1915; it mentions the titles as signaled by the Jesuit authors themselves, and in many cases it is very incomplete. In total the Moniteur Bibliographique lists only eleven entries by Maurice Potron. Note that it refers to the year 1905 for the offprint, but the original Bulletin article is from 1904 (Potron didn't publish anything in the Bulletin in 1905).

[1904c] "Les $G_{p^{m}}$ ( $p$ premier) dont tous les $G_{p^{m-2}}$ sont abéliens", Bulletin de la Société Mathématique de France, 32: 300-314.

Reviewed in JFM by Alfred Loewy.

[1904d] "Sur les groupes d'ordre $p^{m}$ ( $p$ premier) dont tous les sous-groupes d'ordre $p^{m-2}$ sont abéliens", Comptes Rendus de l'Académie des Sciences, 139: 396-399 (Session of 8 August).

[1904e] "Sur les groupes d'ordre $p^{m}(p$ premier, $m>4)$ dont tous les diviseurs d'ordre $p^{m-2}$ sont abéliens", Comptes Rendus de l'Académie des Sciences, 139: 963-964 (Session of 5 December).

[1905] "Note Bibliographique : J.-A. de Séguier, Eléments de la théorie des groupes abstraits", Etudes, 103: 140-141 (5 April).

Short book review by Potron. 


\section{[1905-1906] Carnets d'Observations.}

The library of the Observatoire de Paris (Archives, Reference number A-F. 14) conserves five carnets bearing Potron's name, that is, five notebooks of astronomical observations made by Potron. Each notebook contains about 37 double pages, with daily observations and computations. The dates are as follows: 4 April 1905 - 8 November 1905 (no observations between 10 June and 6 October); 9 November 1905 - 23 January 1906; 24 January 1906 - 5 March 1906; 5 March 1906 - 28 March 1906; 3 April 1906 - ends unfinished on 1 May 1906.

[1906a] "Sur une formule générale d'interpolation", Bulletin de la Société Mathématique de France, 34: 52-60.

Reviewed in JFM by Carl Weltzien.

[1906b] "Revue de Livre : B. Baillaud \& H. Bourget (Eds.), Correspondance d'Hermite et de Stieltjes”, Etudes, 107: 533 (20 May).

Short book review by Potron.

[1906c] "Revue de Livre : E. Borel, Leçons sur les fonctions de variables réelles et les développements en séries de polynomes/R. Baire, Leçons sur les fonctions discontinues", Etudes, 107: 538-539 (20 May).

The title of this book review by Potron uses "polynomes" instead of the standard "polynômes".

[1906d] "Note Bibliographique : G. Vivanti, Leçons élémentaires sur la théorie des groupes de transformation", Etudes, 107: 856-857 (20 June).

Short book review by Potron.

[1907a] "Note Bibliographique : G. Darboux, Etude sur le développement des méthodes géométriques", Etudes, 110: 139-140 (5 January).

Short book review by Potron.

[1907b] "Note Bibliographique : G. Papelier, Formulaire de mathématiques spéciales", Etudes, 110: 428 (5 February).

Short book review by Potron. 
[1911a] "Communication". Included as a footnote pp. 175-176 in G. Desbuquois, "La justice dans l'échange", in: Semaine Sociale de France. Cours de Doctrine et de Pratique Sociales. Bème Session - Saint-Étienne 1911. Compte rendu in-extenso. Lyon: Chronique Sociale de France, pp. 165-177. Identical footnote pp. 882-883 in G. Desbuquois, "La loi du juste prix ”, Le Mouvement Social, 72: 867-884 (October).

This "communication" is a footnote of about 700 words by Potron, who provides a nonmathematical summary of his two forthcoming articles [1912a] and [1913a]. This long footnote has no title, but Potron's results are "communicated" by Desbuquois, and Potron himself [1911b, p. 4] also refers to this as a "communication". Desbuquois read his paper in Saint-Etienne, in the Semaine Sociale, on 1 August 1911 (see the conference programme in Année Sociale Internationale, Reims: Action Populaire, 1911, p. 44). The imprimatur of the Semaine Sociale proceedings was given on 4 November 1911, and so the proceedings were published after the October issue of Mouvement Social. The two papers by Desbuquois choose a different title, but contain an almost identical text, except that the version in the Semaine Sociale proceedings is more readable, because it adds titles for the different sections and paragraphs. "La loi du juste prix" by Desbuquois also appeared as "brochure 251" from Action Populaire, Série Sociale.

[1911b] “A propos d'une contribution mathématique à l'étude des problèmes de la production et des salaires", Echos de l'Union Sociale d'Ingénieurs Catholiques et des UnionsFédérales-Professionnelles de Catholiques, vol. 2, no. 7: 4-7 (15 October). Identical text in: Echos des Unions-Fédérales-Professionnelles de Catholiques, vol. 2, no. 7: 4-7 (15 October).

This is the first article that displays Potron's mathematical economics. It announces [1912a] and [1913a], and gives a mathematical summary of these two forthcoming articles.

In 1911 the Union Sociale d'Ingénieurs Catholiques (USIC) and the Unions-FédéralesProfessionnelles de Catholiques (UFPC) issued two highly overlapping journals, both containing the same Potron article. The two journals used erratically changing titles and numbering systems. (The cover of the 15 October 1911 issue of the first journal mentions vol. 3 instead of vol. 2, but that seems to be a numbering error).

An offprint of Potron's article, not dated and not containing the opening and closing paragraph, is available in the Archives Jésuites de la Province de France in Vanves, and is reprinted in [2004: 57-62]. This offprint mentions: Extrait des 'Echos de l'Union Sociale d'Ingénieurs Catholiques". Copies of the original 1911 Echos were recently found in the archives of the Mouvement Chrétien des Cadres et Dirigeants (MCC), Paris. 
[1911c] "Quelques propriétés des substitutions linéaires à coefficients $\geq 0$ et leur application aux problèmes de la production et des salaires", Comptes Rendus de l'Académie des Sciences, 153: 1129-1132 (Session of 4 December). Errata p. 1541.

Reprinted in [2004: 63-66]. Reviewed in JFM by Ernst Jacobsthal (student of Frobenius).

[1911d] “Application aux problèmes de la 'production suffisante' et du 'salaire vital' de quelques propriétés des substitutions linéaires à coefficients $\geq 0$ ", Comptes Rendus de l'Académie des Sciences, 153: 1458-1459 (Session of 26 December).

Reprinted in [2004: 67-68]. Reviewed in JFM by Ernst Jacobsthal.

[1912a] "Possibilité et détermination du juste prix et du juste salaire", Le Mouvement Social, 73: 289-316 (15 April). Also published by Maison Bleue (Paris) as "brochure 274", Action Populaire, Série Sociale.

Reprinted in [2004: 69-93].

Potron's Mouvement Social article is listed in American Economic Review, December 1912, p. 979 in the section "Periodical Abstracts. Theory" by Walter Adriance, but, unlike for most other articles, Adriance provides no abstract for Potron's text. Also listed in many other journals, for example in La Réforme Sociale, 1-16 August 1912, p. 215, in the section "Revue des revues de langue française" by Paul Doin, who is more informative: "L'auteur est un mathématicien; il prétend établir la possibilité de résoudre le problème du juste salaire et du juste prix à l'aide d'équations".

[1912b] “Contribution mathématique à l'étude des problèmes de la production et des salaires", Journal de la Société de Statistique de Paris, 53: 247-249 (May).

According to the editorial introduction, this is part of a letter from Potron to the Journal. The text appeared in the section "Variéte", and was published without a title. The above title was given in the table of contents.

Reprinted in [2004: 95-100]. Listed (using the above title) in American Economic Review, December 1912, p.1031 in the section "Periodical Abstracts. Statistics" by Allyn Young, who gives the following vague summary of this nonmathematical text by Potron: "Proposes a method of determining the cost of living in terms of all the products (and labor) used up in the production of consumption goods." 
[1912c] Relations entre la Question du Chômage et Celles du Juste Prix et du Juste Salaire. Mimeo conserved in the library of the Université Catholique de l'Ouest (Angers), catalogue number TU908-3-2, date uncertain, 3 p.

[1913a] "Quelques propriétés des substitutions linéaires à coefficients $\geq 0$ et leur application aux problèmes de la production et des salaires", Annales Scientifiques de l'Ecole Normale Supérieure, 3ème série, 30: 53-76.

Reprinted in [2004: 101-126].

Reviewed in JFM by Ludwig Bieberbach, who notes that most of Potron's mathematics will be recognized by German readers of Perron and Frobenius.

[1913b] "Compte rendu des compositions de mathématiques du concours général des Facultés Catholiques de l'Ouest pour 1913”, Bulletin des Facultés Catholiques de l'Ouest, 20, no. 4, (September): 3-5.

The text contains comments by Potron on the results of the "concours général" of 10 June 1913. The above title was used by Potron in the 1913 list of the Moniteur Bibliographique (for more information on the Moniteur Bibliographique, see entry [1904b]).

[1914a] "Contribution mathématique à l'étude de l'équilibre entre la production et la consommation", in: L. Varlez \& M. Lazard (Eds.), Assemblée Générale de l'Association Internationale pour la Lutte contre le Chômage. Gand, 5-6 Septembre 1913. Procès-verbaux des Réunions et Documents Annexes. Paris: Service des Publications de l'Association Internationale pour la Lutte contre le Chômage, Annexe VII, pp. 163-171. Identical text by Potron appeared in Bulletin Trimestriel de l'Association Internationale pour la Lutte contre le Chômage, 1914, vol. 4, no. 2, pp. 509-517.

Although Potron's paper was not presented at the 1913 conference in Ghent (Gand), it was included as one of the appendices in the conference book in 1914. The articles from the conference book also appeared in various issues of the Bulletin. When later citing his own contribution, Potron [1914c, p. 505] referred to the book, not to the Bulletin.

[1914b] "Revue de Livre : M. Gandillot, Abrégé sur l'hélice et la résistance de l'air", Etudes, 139: 141-142 (5 April).

Short book review by Potron. 
[1914c] "L'organisation scientifique du travail. Le Système Taylor. A. Les Principes", Le Mouvement Social, 77: 497-510 (15 June).

Cited by Angelo Mariotti in 1918 in a footnote p. 49 of his article "L'organizzazione razionale del lavoro", Rivista Italiana di Sociologia, 22: 48-73.

[1914d] "L'organisation scientifique du travail. Le Système Taylor. B. Les Sanctions de l'Expérience", Le Mouvement Social, 78: 21-33 (15 July).

[1919] "Monde (Le Système du)", in: Adhémar d'Alès (Ed.), Dictionnaire Apologétique de la Foi Catholique contenant les Preuves de la Vérité de la Religion et les Réponses aux Objections tirées des Sciences Humaines. Quatrième édition entièrement refondue. Tome 3, Fascicule 15, Modernisme - Musique religieuse. Paris: Beauchesne. Columns 867-878.

The Dictionnaire Apologétique was a well-known Catholic encyclopedia, whose first three editions had been edited by Jean-Baptiste Jaugey at the end of the $19^{\text {th }}$ century. The present fourth edition was a much larger and completely revised work, edited by Adhémar d'Alès, professor at the Institut Catholique de Paris.

The 8000 subscribers received 24 paperback Fascicules, starting with "Agnosticisme Aumône" in 1909 and ending with "Templiers - Zoroastre" in 1928. The Fascicules were then put together in four hardcover Tomes. A supplement with an index was published in 1931. Potron's article appeared in Fascicule 15, which was first published in 1919. (See the 1920 review of Fascicules 10 to 15 by Ferdinand Cavalerra in Nouvelle Revue Théologique, 47: 59-62).

Today many libraries own hardcover editions of the encyclopedia, in which Potron's text is found in Tome 3, which contains Fascicules 13 to 18. In some hardcover editions the title page of Tome 3 mentions the year 1916, but this refers to the publication year of Fascicule 13, the first of this Tome (other hardcovers of Tome 3 mention 1926, but this is the year of a reprint). Each of the four Tomes contains almost a thousand pages printed in two numbered columns.

Potron's contribution "Le Système du Monde" describes the history of cosmological doctrines, from ancient Greece via Copernicus, Galileo, Kepler and Newton to his contemporaries Poincaré and Lorentz (Einstein is not mentioned). Potron is clearly inspired by Pierre Duhem's multivolume work Le Système du Monde. Contrary to many of Potron's other writings, this 1919 contribution by Potron provides a very extensive bibliography, containing more than fifty items. 
[1921] "Sur une représentation du groupe des 27 droites en groupe de collinéations quaternaires", Comptes Rendus de l'Académie des Sciences, 173: 346-348 (Session of 8 August).

[1922a] (with François Michel) La Composition de Mathématiques dans l'Examen d'Admission à l'Ecole Polytechnique de 1901 à 1921: Exercices d'Application du Cours de Mathématiques Spéciales. Paris: Gauthier-Villars, 452 p.

Reviewed in JFM by Leon Lichtenstein. Other book reviews exist, for example by M.O. in Revue des Questions Scientifiques, April 1923, pp. 536-537, and by Tomlinson Fort in American Mathematical Monthly, May-June 1923, p. 201.

[1922b] "Sur le groupe quaternaire primitif d'ordre 25920", Journal de l'Ecole Polytechnique, 2ème série, 22: 69-89.

[1926a] "Sur les théorèmes fondamentaux de la théorie des groupes continus finis de transformations", Comptes Rendus de l'Académie des Sciences, 183: 841-842 (Session of 8 November).

Reviewed in JFM by Hans Freudenthal.

[1926b] "Revue de Livre : Colonel Compaing de la Tour-Girard. Les outils. Leur étude géométrique", Etudes, 189: 511-512 (20 November).

This book review is signed M.P. (It is not sure that this is Maurice Potron).

[1926-1927] Exercices de Calcul Différentiel et Intégral. Volume 1 : Résumé Théorique et Enoncés d'Exercices. Volume 2 : Solutions des Exercices. Paris: Hermann, $332+$ $258 \mathrm{p}$.

Widely available. Volume 1 was reviewed by Helmut Grunsky in JFM, and by Jacob David Tamarkin in the Bulletin of the American Mathematical Society, 1927, pp. 670-671. Both volumes 1 and 2 received reviews by Fernand Simonart in Revue des Questions Scientifiques (20 January 1927, pp. 183-184; 20 January 1928, p. 156), by Raymond Alezais in Etudes (5 March 1927, pp. 637-638; 20 December 1927, p. 758), and by many others.

[1927a] "Sur les partages d'un système d'entiers en groupes de sommes données", Comptes Rendus de l'Académie des Sciences, 184: 572 (Session of 7 March).

Reviewed in JFM by Arnold Scholz. 
[1927b] “Sur les partages d'un système d'entiers en groupes de sommes données”, Journal de l'Ecole Polytechnique, 2ème série, 26: 39-43.

[1927c] "Quelques remarques sur les équations aux dérivées partielles et les intégrales singulières des équations différentielles", Nouvelles Annales de Mathématiques, 6ème série, 2: 78-82 (March).

Reviewed in JFM by Oskar Perron, the famous German pioneer of the Perron-Frobenius theory of nonnegative matrices. Note that $[1927 \mathrm{c}]$ is not related to Perron-Frobenius theory, and that Maurice Potron made a bizarre error in [1912a, p. 291] by characterizing Oskar Perron as a "Swedish mathematician".

[1927d] "Sur les théorèmes fondamentaux de la théorie des groupes continus finis de transformations”, Bulletin des Sciences Mathématiques, 2ème série, 51: 91-96 (I), 101-114 (II).

Reviewed in JFM by Hans Freudenthal.

[1931a] "Sur l'irrationalité du nombre $\pi ”$, Revue de Mathématiques Spéciales, 41: 473-475 (April).

Reviewed in JFM by Helmut Wielandt.

[1931b] "Sur un théorème fondamental de la théorie des groupes continus finis de transformations", Comptes Rendus de l'Académie des Sciences, 192: 1302-1304 (Session of 18 May).

Reviewed in JFM by Hans Freudenthal, and in Zbl by Hans Schwerdtfeger.

[1932a] "Sur l'irréductibilité des polynomes à plusieurs variables", Bulletin de la Société Mathématique de France, 60: 127-128.

The title uses "polynomes" instead of the standard "polynômes". Reviewed in JFM by Karl Molsen.

[1932b] "Sur un type de problèmes de cinématique résolus par l'intégrale singulière d'une équation différentielle”, Revue de Mathématiques Spéciales, 42: 217-218 (June). 
[1932c] "Sur certaines transformations conformes dans un espace de Riemann", Comptes Rendus de l'Académie des Sciences, 195: 747-749 (Session of 2 November).

[1932d] "Sur les espaces de Riemann admettant un groupe de transformations isométriques à $n(n+1) / 2$ paramètres", Comptes Rendus de l'Académie des Sciences, 195: 850-2 (Session of 14 November).

Reviewed in JFM by Willi Rinow, and in Zbl by Hans Schwerdtfeger.

[1934a] "Sur les espaces de Riemann admettant un groupe isométrique à $n(n+1) / 2$ paramètres", Journal de Mathématiques Pures et Appliquées, 9ème série, 13: 197216.

Reviewed in JFM by Hans Freudenthal, and in Zbl by Otakar Boruvka.

[1934b] "Sur l'intégrale de différentielle binome", Bulletin de la Société Mathématique de France, 62, Supplément Spécial (Vie de la société), Comptes Rendus des Séances de l'Année 1934: 36-39 (Session of 11 April).

The title uses "binome" instead of the standard "binôme".

[1934c] "Sur la différentielle binôme", Bulletin Mathématique des Facultés des Sciences et des Grandes Ecoles, Tome I, 6: 161-169 (June).

The last two lines of page 167 are corrected by a "Complément" in Tome I, 8: 247 (September-October). Reviewed in JFM by Helmut Grunsky, and in Zbl by Lothar Schrutka.

[1934d] "Sur les normalisants des $s_{2}$ dans les groupes gauche et quadratique", Annales Scientifiques de l'Ecole Normale Supérieure, 3ème série, 51: 141-151.

Reviewed in JFM by Helmut Wielandt, and in Zbl by Bartel van der Waerden.

[1935a] "Sur l'intégrale de différentielle binome", Journal de l'Ecole Polytechnique, 2ème série, 33: 161-174.

The title uses "binome" instead of the standard "binôme".

Reviewed in JFM by Wilhelm Maier, and in Zbl by Lothar Schrutka. The offprint, published by Gauthier-Villars in Paris, is reviewed by Adolphe Buhl in L'Enseignement Mathématique, 1934, vol. 33, p. 248, and by Robert de Montessus de Ballore in Revue Générale des Sciences Pures et Appliquées, 1934, vol. 45, p. 604 (offprint and journals printed in 1935). 
[1935b] "Sur une expression de la courbure tangentielle d'une courbe tracée sur une surface", Bulletin Mathématique des Facultés des Sciences et des Grandes Ecoles, Tome II, 4: 97-101 (April).

Reviewed in JFM by Karl-Heinrich Weise.

[1935c] "Sur l'irréductibilité des polynomes à plusieurs variables", Bulletin de la Société Mathématique de France, 63: 226-230.

The title uses "polynomes" instead of the standard "polynômes".

Reviewed in JFM by Werner Schulz, and in Zbl by Nikolai Tschebotarjow.

[1935d] "Sur certaines conditions de l'équilibre économique. Lettre de M. Potron (90) à R. Gibrat (22)", Centre Polytechnicien d'Etudes Economiques. X-Crise. Bulletin Mensuel, nos. 24-25: 62-65 (July-August).

Reprinted in [2000: 153-160] and [2004: 127-136].

This is a letter from Maurice Potron to Robert Gibrat. The notation "M. Potron (90)" indicates that Potron entered the Ecole Polytechnique in the year 1890 (Gibrat in 1922).

Several articles from $X$-Crise, including this one by Potron, are mentioned by the Swiss engineer Charles Jaeger, on p. 51 of the bibliography in his 1937 article "Quelques aspects récents de l'emploi des mathématiques en économie politique", Schweizerische Bauzeitung, 110: 45-51. Jaeger again mentions Potron's name, and again without further details, in a list of related writers on mathematical economics, on p. 279 in another 1937 article "Le problème de la prévision en économique rationnelle", Zeitschrift für Schweizerische Statistik und Volkswirtschaft, 73: 279-286.

In the first footnote of his $X$-Crise letter, Potron refers to the following text of his own: "Les équilibres production-consommation et prix-salaires (Editions S.P.E.S., 17, rue Soufflot, Paris 5)". Most probably, S.P.E.S. ultimately did not publish this Potron text.

[1936a] Les Groupes de Lie. (Mémorial des Sciences Mathématiques, 81). Paris, GauthierVillars, $64 \mathrm{p}$.

Reviewed in JFM by Friedrich Engel. 
[1936b] Communication faite au Congrès d'Oslo. Draft of Potron's communication at the International Congress of Mathematicians in Oslo (July 1936). Mimeo conserved in the Archives Jésuites de la Province de France in Vanves, date uncertain. Reprinted in [2004: 137-139].

The title at the top of the typed text is handwritten by Potron himself. The shorter published abstract of this communication is [1937b].

[1937a] "Sur l'irréductibilité de certaines intégrales abéliennes aux transcendantes élémentaires", Comptes Rendus du Congrès International des Mathématiciens. Oslo 1936. Oslo: A. W. Brøggers Boktrykkeri A/S, vol. 2: 89-90.

[1937b] "Sur les équilibres économiques", Comptes Rendus du Congrès International des Mathématiciens. Oslo 1936. Oslo: A. W. Brøggers Boktrykkeri A/S, vol. 2: 210-211. Reprinted in [2004: 141-142].

Short abstract of Potron's communication in Oslo (for the longer draft, see [1936b]). In 1936, various mathematical journals published lists of the Oslo sessions. In these lists, Potron's economic presentation is entitled "Conditions des équilibres productionconsommation et prix-salaires" (See Fehr, Henri (1936). "Le 10e Congrès International des Mathématiciens. Oslo, 13-18 Juillet 1936”, L’Enseignement Mathématique, 35: 375-385. See also Morse, Marston (1936). "The International Congress in Oslo", Bulletin of the American Mathematical Society, 42: 777-781).

[1937c] "Sur les matrices non négatives", Comptes Rendus de l'Académie des Sciences, 204: 844-846 (Session of 8 March).

Reviewed in JFM by Helmut Wielandt, and in Zbl by Cyrus MacDuffee. Cited by Rufus Oldenburger in 1940 in "Infinite powers of matrices and characteristic roots", Duke Mathematical Journal, 6: 357-361.

[1937d] “Travaux de Camarades”, Centre Polytechnicien d'Etudes Economiques. X-Crise, no. 36: 57 (March).

Potron announces and summarizes his forthcoming six lectures on "Les rapports existant entre certains problèmes économiques et quelques acquisitions assez récentes d'une théorie mathématique". The text of these six lectures is found in [1937e]. 
[1937e] L'Aspect Mathématique de Certains Problèmes Economiques en Relation avec de Récentes Acquisitions de la Théorie des Matrices Non Négatives, unpublished text (34 p.) of six lectures presented at the Institut Catholique de Paris in March-April 1937, and an appendix (5 p.) entitled Le Problème de la Manne des Hébreux.

Reprinted in [2004: 143-203].

According to the bibliography in [1939a, p. 61] this text was already available in "Paris, 1936, chez l'auteur". Listed in Journal de la Société de Statistique de Paris, 1937, vol. 78, p. 259. Available in the Archives Jésuites de la Province de France in Vanves, and in the library of Université de Bordeaux 1 (Sciences et Techniques - Talence), reference FR 19069. Reviewed by Alfred Barriol in 1942 in the Journal de la Société Statistique de Paris, 83: 205-207; moreover pp. 203-204 of the same issue present an obituary of Potron by Barriol, and pp. 207-208 contain a letter by Potron himself on industrial statistics (see [1942a] below).

On 26 March 1953 an internal Jesuit report by Michel Vittrant condemned Potron's numerical examples in the appendix as ridiculously unrealistic, and then suggested that further study of Potron's work was useless (report in the Archives Jésuites de la Province de France in Vanves).

[1938a] (with Jean Armand de Séguier) Théorie des Groupes Abstraits (Mémorial des Sciences Mathématiques, 91). Paris: Gauthier-Villars, 41 p.

Reviewed in JFM by Helmut Wielandt, and in Zbl by Helmet Ulm.

[1938b] La Décoration des Surfaces Planes. Mimeo conserved in the Archives Jésuites de la Province de France (Vanves), 12 p.

Listed in the section "Ouvrages Reçus" of the Journal de la Société de Statistique de Paris, June 1938, p. 146, with "Décorations" instead of the correct "La Décoration" in the title.

[1939a] "Sur les matrices non négatives et les solutions positives de certains systèmes linéaires", Bulletin de la Société Mathématique de France, 67: 56-61.

Reviewed in JFM by Elisabeth Schulenberg, in MR by Isaac Schoenberg, and in Zbl by Nikola Obrechkoff. Mentioned, without further explanation, on p. 362 in the bibliography of the following paper: Woodbury, Max A. (1954), "Properties of Leontief-type input-output matrices", in: Morgenstern, Oskar (Ed.), Economic Activity Analysis, New York: Wiley, pp. 341-363. This inconspicuous reference to Potron by Woodbury didn't draw the attention of other input-output specialists, and Woodbury himself concentrated on a wide variety of other topics in the rest of his successful career. 
[1939b] Lettres du P. Potron au P. Hoenen à propos de ses articles du Gregorianum en 1938-1939. Copie ddct. par les soins de P. J. Abelé. File conserved in the Archives Jésuites de la Province de France (Vanves), date uncertain.

This file in the Archives Jésuites de la Province de France in Vanves was compiled by the French Jesuit Jean Abelé (1886-1961). It contains a one page introduction by Abelé, then one letter from Potron to Hoenen dated 18 December 1939, then five pages of unpublished notes by Potron on the philosophy of mathematics ("Sur la philosophie des sciences mathématiques"), and seven pages by Potron that comment on three articles by Hoenen.

The Dutch Jesuit Peter Hoenen (1880-1961) was professor of cosmology and philosophy of science at the Gregorian University in Rome. Its journal Gregorianum contained the following three Hoenen articles studied by Potron: "De philosophia scholastica cognitionis geometricae" (1938, vol. 19, fasc. 4, pp. 498-514); "De problemate necessitatis geometricae" (1939, vol. 20, fasc. 1, pp. 19-54); "De problemate exactitudinis geometricae” (1939, vol. 20, fasc. 3, pp. 321-350).

Note that Abelé also mentions the existence of other unpublished (unfound) material by Potron, mainly constituted by his lecture notes at the Institut Catholique de Paris. Abelé singles out Potron's course on general topology, a subject "that is rarely cultivated in France".

[1940a] "Sur la décomposition d'un groupe continu fini", Journal de Mathématiques Pures et Appliquées, 9ème série, 19: 143-161.

Reviewed in JFM by Friedrich Engel, in MR by Richard Brauer, and in Zbl by Hans Zassenhaus.

[1940b] "Sur les fondements de l'arithmétique", Revue Générale des Sciences Pures et Appliquées, 51: 141-144.

[1942a] "Lettre sur les statistiques industrielles", Journal de la Société de Statistique de Paris, 83: 207-208.

This is a letter from Potron, commenting on Alfred Sauvy's 1941 article "Les statistiques industrielles”, Journal de la Société de Statistique de Paris, 82: 131-145.

Potron's text appeared in the section "Variété", and was published without a title. The above title was given in the table of contents.

Reprinted in [2004: 205-207]. 
[1942b] "Orientations nouvelles de l'enseignement des mathématiques", Le Xavier (Collège Saint François-Xavier. Revue trimestrielle), Vannes, Pâques 1942, no. 52: 16-18. A copy is available in the Municipal Archives in Vannes.

\section{Section 2. Republications after 1942}

[2000] "Sur certaines conditions de l'équilibre économique. Lettre de M. Potron (90) à R. Gibrat (22)", Cahiers d'Economie Politique, no. 36: 153-160.

This is a reprint of [1935d], introduced by E. Lendjel, "Une contribution méconnue dans l'histoire de la pensée économique : le modèle de l'Abbé M. Potron (1935)", Cahiers d'Economie Politique, no. 36: 145-151.

[2004] Les Oeuvres Economiques de l'Abbé Potron. Edited and introduced by G. AbrahamFrois and E. Lendjel. Paris: L'Harmattan, 220 p.

This French edition republishes many important economic articles by Potron, as indicated in Section 1 above.

[2010 forthcoming] The Analysis of Linear Economic Systems. Father Maurice Potron's Pioneering Works. Edited and introduced by C. Bidard and G. Erreygers. London and New York: Routledge.

English translations of all the relevant economic publications by Potron, thus comprising some papers not included in [2004]. Bidard and Erreygers also translate three short French texts related to Potron: first the Potron obituary written by Alfred Barriol, second Barriol's review of Potron [1937e], and third the very negative internal report on the appendix of [1937e] by Michel Vittrant. For more information on Barriol and Vittrant, see entry [1937e]. 


\section{Section 3. Solutions to Examination Sessions in the 1930s}

In the 1920s Potron had published some widely available books with mathematical exercises and solutions (see [1922a] and [1926-1927] above). Later he again provided exercises and solutions, this time with respect to the examination sessions for the Certificat de Calcul Différentiel et Intégral (C.D.I.) in all the Faculties of France in the 1930s. Potron's solutions were first available in various issues of the Bulletin Mathématique des Facultés des Sciences et des Grandes Ecoles, a journal concentrating on the teaching of mathematics. This journal ran only five volumes: vol. I appeared in 1934, II in 1935, III in 1937 (but is officially called “year 1936”), IV in 1938, V in 1939.

Potron's solutions were then bundled in short books, some of which had a provisional nature. Of course, these exercises are less important from a scholarly point of view. None of the short books was deposited in the Bibliothèque Nationale de France. In some cases a copy could be traced in foreign libraries. In other cases I can prove the existence of the item only by referring to advertisements, relevant book reviews, or lists of works received at the editorial offices of some journals.

The references [SA1] to [SA9] below contain the solution articles in the Bulletin Mathématique des Facultés des Sciences et des Grandes Ecoles, abbreviated below as Bull. Math. Fac. The reprints in the solution booklets are described in references [SB1] to [SB6].

[SA1] "Calcul différentiel et intégral. Session de juin 1933 avec indications sur les solutions par M. l'abbé Potron”, Bull. Math. Fac., February 1934, 49-64; March 1934, 82-84.

[SA2] "Calcul différentiel et intégral. Session de novembre 1933”, Bull. Math. Fac., March 1934, 85-96; April 1934, 109-129.

[SA3] "Calcul différentiel et intégral. Juin-juillet 1934. Avec indication des solutions par M. l'Abbé Potron”, Bull. Math. Fac., September-October 1934, 254-256; November 1934, 271-288; December 1934, 305-318; January 1935, 19-23. 
[SA4] "Calcul différentiel et intégral. Session de novembre 1934 avec indication des solutions par M. l'Abbé Potron”, Bull. Math. Fac., January 1935, 24-32; February 1935, 46-64; March 1935, 79-86.

[SA5] "Calcul différentiel et intégral. Enoncés et indications sur les solutions par M. 1'abbé Potron. Session de juin 1935”, Bull. Math. Fac., February 1936, 47-64; March 1936, 77 92.

[SA6] "Calcul différentiel et intégral. Session de novembre 1935", Bull. Math. Fac., March 1936, 93-96; April 1936, 110-128; May 1936, 141-155.

[SA7] "Agrégation des Sciences mathématiques. Concours de 1937. Problème de calcul différentiel et intégral. Solution par l'abbé Potron", Bull. Math. Fac., April 1938, $97-$ 110 .

Here Potron solves the problem that was announced on pp. 26-28 of the January 1938 issue.

[SA8] "Calcul différentiel et intégral. Première session de 1937. Enoncés et indications sur les solutions par M. l'abbé Potron", Bull. Math. Fac., July-August 1938, 211-224; September-October 1938, 235-256; November 1938, 281-288; December 1938, 314318; January 1939, 18-23.

[SA9] "Calcul différentiel et intégral. Deuxième session de 1937”, Bull. Math. Fac., January 1939, 24-32; February 1939, 45-64; March 1939, 77-84.

[SB1] Exercices de Calcul Différentiel et Intégral. Solutions des Problèmes Posés au C.D.I. dans les Facultés de France en Juin-Juillet 1933. Paris: Hermann, 1933, 44 p. Information for this unseen reference is taken from the book review by Adolphe Buhl (1933) in L'Enseignement Mathématique, 32: 286-287, which signals "ce premier cahier a un aspect provisoire" (p. 287). 
[SB2] Solutions des Problèmes Donnés au Certificat de Calcul Différentiel et Intégral, à la session de Juin-Juillet 1933, dans toutes les Facultés de France. Paris: Hermann, 1933, $50 \mathrm{p}$.

Information for this unseen reference is taken from the list of "Ouvrages Récemment Parus" in the Revue des Questions Scientifiques, 1934: 160-161, where the anonymous description is similar to the first part of the review by Adolphe Buhl mentioned in [SB1]. It is probable that [SB2] is a slightly longer and later version of [SB1].

[SB3] Certificat de Calcul Différentiel et Intégral. Solutions des Problèmes Posés à la Session de Juin 1933. Paris: Hermann. Year unknown.

This unseen reference is mentioned in an advertisement on the frontispiece of [SB6]. Given this 1936 advertisement, [SB3] is probably a more definitive text than [SB1] and [SB2].

[SB4] Certificat de Calcul Différentiel et Intégral. Solutions des Problèmes Posés à la Session de Novembre 1933. Paris: Croville-Morant. Year unknown.

This unseen reference is mentioned in an advertisement on the frontispiece of [SB6]. Probably it was published only at the end of 1935, because Potron complained about the long delays in publishing the booklet with the solutions for November 1933 (see Potron's letter to Raymond Alezais, dated 17 July 1935, conserved in the Archives Jésuites de la Province de France in Vanves).

[SB5] Exercices de Calcul Différentiel et Intégral. Paris: Hermann, 1934, 43 p.

This unseen reference is reviewed by Robert de Montessus de Ballore in Revue Générale des Sciences Pures et Appliquées, 1934, vol. 45, pp. 603-604, mentioning “M. 1'Abbé Potron rend un service éminent aux étudiants en publiant les solutions des problèmes posés au certificat de Calcul différentiel et intégral dans les facultés de France, en juin-juillet 1934."

This short book is also included in the list of new publications in the Bulletin of the American Mathematical Society, 41, no. 3, March 1935: 205-208.

[SB6] Calcul Différentiel et Intégral. Certificat d'Etudes Supérieures. Sessions de 1934. Enoncés et Indications sur les Solutions. Paris: Hermann, 1936, 74 p.

Advertised in many issues of the Bulletin Mathématique des Facultés des Sciences et des Grandes Ecoles. A copy is available in the library of the Universität des Saarlandes (Germany), catalogue number 52-11156, and in the Universidade de Santiago de Compostela (Spain), Biblioteca de Matemática, catalogue number 26317. 